\title{
The absence of D-alanine from lipoteichoic acid and wall teichoic acid alters surface charge, enhances autolysis and increases susceptibility to methicillin in Bacillus subtilis
}

\author{
Jörg Wecke, ${ }^{1}$ Kazimierz Madela' and Werner Fischer ${ }^{2}$ \\ Author for correspondence: Jörg Wecke. Tel: +49304547 2219. Fax: +493045472606.
}

1 Robert Koch-Institut, D13353 Berlin, Germany

2 Institut for Biochemie, University ErlangenNurnberg, D-91054 Erlangen, Germany

\begin{abstract}
In Bacillus subtilis the physiological consequences of depriving lipoteichoic acid and wall teichoic acid of D-alanine ester were analysed using insertional inactivation of the genes of the dlt operon. Mutant strains which lacked positively charged $\mathrm{D}$-alanine ester in teichoic acids bound more positively charged cytochrome $c$ than other strains. These mutant strains also showed enhanced autolysis and a higher susceptibility to methicillin, which was expressed as accelerated wall lysis, a faster loss of viability and a slower recovery in the postantibiotic phase. The effects of methicillin could be suppressed by simultaneous addition of magnesium ions at low concentrations. The degradation of whole bacteria by bone-marrow-derived macrophages was not influenced by the surface charge and alanylation of the teichoic acids had no protective effect.
\end{abstract}

Keywords: Bacillus subtilis, lipoteichoic acid, wall teichoic acid, autolysis, methicillin

\section{INTRODUCTION}

Lipoteichoic acids (LTAs) have been proposed to play an important role in the regulation of wall autolytic enzymes (Cleveland et al., 1975; Höltje \& Tomasz, 1975). However, the molecular basis of the regulation is unknown. The D-alanine ester substitution of LTA has repeatedly been suggested to be connected with the physiological role of LTA (Fischer, 1988; Lambert et al., 1977). The positively charged D-alanyl ester residues apparently affect the binding of cations to cell-walllinked teichoic acids (WTAs) by reducing the number of binding sites (Lambert et al., 1975). Experiments with $\mathrm{Mg}^{2+}$-dependent enzymes located in the cytoplasmic membrane of Bacillus licheniformis demonstrated that this cation activated the enzymes, possibly via binding to WTA (Hughes et al., 1973). On the other hand, $\mathbf{M g}^{2+}$ may suppress the activity of wall autolytic enzymes, as has been shown with penicillin-treated staphylococci (Kersten \& Wecke, 1993).

Since the discovery of the dlt operon in Lactobacillus casei (Heaton \& Neuhaus, 1992, 1994; Neuhaus et al., 1996; Debabov et al., 1996) and Bacillus subtilis (Perego et al., 1995), insertional inactivation of the genes encoding the proteins involved in alanylation of LTA and WTA allows investigation of the effect of the absence of positively charged D-alanine ester, which renders the polyglycerophosphate chains purely anionic. In B. subtilis four proteins are involved in the alanylation process (Perego et al., 1995). The gene dltC encodes the D-alanine carrier protein (Dcp). The proposed functions of the proteins encoded by the other genes are briefly: $\operatorname{dlt} A$, ligation of $\mathrm{D}$-alanine to $\mathrm{Dcp}$ via $\mathrm{D}$-alanyl AMP; $d l t B$, transport of activated $\mathrm{D}$-alanine in a not yet defined form through the cytoplasmic membrane; $d l t D$, transfer from the transport form to LTA and possibly WTA, unless WTA is alanylated by $\mathrm{D}$-alanyl transfer from $\mathrm{D}$ Ala-LTA as shown earlier with Staphylococcus aureus (Haas et al., 1984; Koch et al., 1985). The fifth gene of the dlt operon of B. subtilis, dltE, has no function in the D-alanylation process (Perego et al., 1995). Accordingly, the mutant defective in this gene has normally alanylated WTA and LTA and it was therefore used in this study together with the wild-type strain JH642 as a control.

Recently we used insertional inactivations of the different genes of the dlt operon in B. subtilis and found that depriving LTA and WTA of D-alanine ester has no detectable effect on cell growth, basic metabolism, cellular content of phosphorus-containing compounds, ultrastructure, cell separation and formation of flagella 
(Wecke et al., 1996). There was, however, a significantly enhanced autolysis of the cells in which LTA and WTA were lacking in $\mathrm{D}$-alanine ester.

In the present study we extend the latter experiments and demonstrate an increase of the negative charge of the cell walls, accelerated autolysis and enhanced methicillin-induced lysis. D-Alanine ester thus provides limited protection of the bacterium against methicillin. However, it does not protect the bacterium against phagocytosis and degradation in macrophages.

\section{METHODS}

Materials. N-Acetyl-D- $\left[1-{ }^{14} \mathrm{C}\right]$ glucosamine $\left(2 \cdot 11 \mathrm{GBq} \mathrm{mmol}^{-1}\right)$ was purchased from Amersham, cytochrome $c$ from Merck, Dulbecco's modified minimum essential medium (D-MEM) and HEPES buffer from Biochrom, glutaraldehyde and osmium tetroxide from Serva, LR white plastic resin from Science Services, methicillin (sodium salt) from Sigma, and Noble agar from Difco.

Bacterial strains and growth. Bacillus subtilis JH642 (wildtype) and the isogenic mutants listed below were prepared and characterized as described by Perego et al. (1995). The following mutants were used, with the insertionally inactivated genes given in parentheses (for the function of the proteins encoded by these genes; see Introduction): DLT65A (dltA), DLT72 (dltB), DLT77 (dltC), DLT74A (dltD), DLT76 $(d l t E)$. The D-alanine content [mol (mol phosphorus) $\left.{ }^{-1}\right]$ of LTA was 0.44 in the wild-type JH642 and 0.49 in the mutant DLT76; in the WTA of both strains it was 0.09. In all other mutant strains no alanine was detected either in LTA or WTA. In all strains LTA was additionally substituted with $\mathrm{N}$-acetylD-glucosamine $\left[0.1-0.2 \mathrm{~mol}\right.$ (mol phosphorus) $\left.{ }^{-1}\right]$, and the WTA with D-glucosyl residues $[0.65 \pm 0.06 \mathrm{~mol}$ (mol phosphorus) $)^{-1}$.

The bacteria were grown aerobically at $37^{\circ} \mathrm{C}$ on a rotary shaker ( 150 r.p.m.) in a medium containing, $1^{-1}$ : casein hydrolysate, $5 \mathrm{~g}$; meat extract, $1.5 \mathrm{~g}$; yeast extract, $1.5 \mathrm{~g}$; glucose, $2 \mathrm{~g}$ (sterilized separately); $\mathrm{K}_{2} \mathrm{HPO}_{4}, 3.68 \mathrm{~g} ; \mathrm{KH}_{2} \mathrm{PO}_{4}$, $1.32 \mathrm{~g}$. The $\mathrm{pH}$ of this medium was adjusted to 7.4 by addition of $1 \mathrm{M} \mathrm{NaOH}$. If not stated otherwise, overnight cultures were diluted with prewarmed medium to $\mathrm{OD}_{578} 0.05$ and incubated for approximately $2.5 \mathrm{~h}$ to obtain cells in the exponential growth phase.

Treatment of bacteria with cytochrome c. Stationary-phase bacteria of the different strains were suspended in $0.1 \mathrm{M}$ HEPES buffer, $\mathrm{pH} 7 \cdot 1$, to $\mathrm{OD}_{578} 1 \cdot 0$. Cytochrome $c$ was added to give concentrations of $500 \mu \mathrm{g} \mathrm{ml}^{-1}$ and $750 \mu \mathrm{g} \mathrm{ml}^{-1}$. After incubation for $10 \mathrm{~min}$ at ambient temperature, the bacteria were removed by centrifugation (12000 r.p.m., 2 min). Binding of cytochrome $c$ was expressed as the difference between the absorbance of the initial concentration $\left(A_{5261}\right)$ and the absorbance in the supernatant after pelleting the bacteria $\left(A_{526 \mathrm{~s}}\right): \Delta A_{526}=A_{5261}-A_{526 \mathrm{~s}}$.

Electron microscopy. The bacteria were fixed overnight at $4{ }^{\circ} \mathrm{C}$ with $2.5 \%(\mathrm{w} / \mathrm{v})$ glutaraldehyde in $0.1 \mathrm{M}$ cacodylate buffer, $\mathrm{pH} 7 \cdot 2$, and, after washing with this buffer, partially postfixed with $1.5 \%(\mathrm{w} / \mathrm{v})$ osmium tetroxide at room temperature for $1 \mathrm{~h}$. The fixed samples were washed again and poststained with $1 \%(\mathrm{w} / \mathrm{v})$ uranyl acetate for $1 \mathrm{~h}$. The fixed and stained bacteria were dispersed in $2 \%(\mathrm{w} / \mathrm{v})$ Noble agar. Small blocks of agar were dehydrated in ethanol and embedded in LR white plastic resin and polymerized at $60^{\circ} \mathrm{C}$ for
$48 \mathrm{~h}$. Thin sections were cut with a Reichert OM U3 ultramicrotome and viewed under a Philips 400 electron microscope.

Microcalorimetry. An LKB 2107 flow-microcalorimeter was used as described by Krüger \& Giesbrecht (1989). A flow rate of $40 \mathrm{ml} \mathrm{h}^{-1}$ was maintained by a peristaltic pump. An instrumental baseline was established by pumping medium through the calorimeter before inoculating the bacteria. The incubation flask $(100 \mathrm{ml})$ containing $60 \mathrm{ml}$ bacterial suspension $\left(\mathrm{OD}_{578} 0.05\right)$ was shaken ( 150 r.p.m.) at $37^{\circ} \mathrm{C}$. The bacterial suspension was pumped through the measuring coil $(0.7 \mathrm{ml})$ of the microcalorimeter and the outflow was returned to the incubation flask. In parallel with microcalorimetric measurements, the $\mathrm{OD}_{578}$ of the culture was continuously recorded in a flow-through photometer (Zeiss PM6) at a flow rate of $60 \mathrm{ml} \mathrm{h}^{-1}$.

Degradation of whole bacteria by macrophages. Bonemarrow cells were isolated from the femur and tibia of 6-8week-old female BALB/c mice (Zentralinstitut für Versuchstierzucht, Hannover, Germany). The cells were seeded on hydrophobic Petriperm dishes (Heraeus) and grown at $37^{\circ} \mathrm{C}$ in an atmosphere containing $5 \% \mathrm{CO}_{2}$ on Dulbecco's modified minimum essential medium (D-MEM) containing $5 \%$ calf serum, $15 \%$ horse serum and $20 \%$ L-cell supernatant as colony-stimulating factor. The cells were re-fed on alternate days starting at day 5 . The cultivation lasted 10-11 d. The cell walls of the bacteria used in this experiment were specifically labelled with $\mathrm{N}$-acetyl-D-[1- $\left.{ }^{14} \mathrm{C}\right]$ glucosamine. To $1.5 \mathrm{ml}$ suspension of exponentially growing bacteria $\left(\mathrm{OD}_{578} 0.2\right) \mathrm{N}$ acetyl-D- $\left[1-{ }^{14} \mathrm{C}\right]$ glucosamine, $92.5 \mathrm{kBq}$, in $100 \mu \mathrm{l}$ water was added. The bacteria were grown at $34^{\circ} \mathrm{C}$ on a shaker overnight to the stationary phase, pelleted by centrifugation, washed twice with cold growth medium and suspended in $1 \mathrm{ml}$ PBS. The bacteria were opsonized with $1 \mathrm{ml} 25 \%$ rabbit antiserum (diluted in D-MEM) for $30 \mathrm{~min}$ at room temperature. Then the bacteria were pelleted by centrifugation and washed twice in $2 \mathrm{ml}$ PBS. After suspension aliquots of these bacteria (about $50 \mu \mathrm{l}$ in $2 \mathrm{ml}$ medium per dish) were added to the macrophages which adhered to the 'biofoil' of Petriperm dishes - approximately $5 \times 10^{5}$ macrophages per dish (50 mm diameter) and about 100 bacteria per macrophage. After $30 \mathrm{~min}$ ingestion the macrophages were washed three times with D-MEM. After 3, 24, 48 and $72 \mathrm{~h}$ incubation the supernatant was withdrawn and replaced by $2 \mathrm{ml}$ fresh $\mathrm{D}$ MEM containing penicillin (100 i.u. $\mathrm{ml}^{-1}$ ) and streptomycin $\left(100 \mu \mathrm{g} \mathrm{ml}^{-1}\right)$ to prevent secondary infection. The ${ }^{14} \mathrm{C}$ radiolabel of the degraded material, released into the supernatant during the time intervals indicated, was measured using a $\beta$ counter from Packard. For each measurement, three dishes were run in parallel.

\section{RESULTS}

\section{Growth of bacteria}

Fig. 1 shows that the growth curves from the early exponential to the stationary phase are identical for the wild-type (JH642) and a mutant strain (DLT74A) that lacks alanine ester on LTA and WTA. The same is true for the concomitant decrease of the $\mathrm{pH}$ from 7.33 to 6.93. Over this $\mathrm{pH}$ range, D-alanine ester is relatively stable in vitro (Childs \& Neuhaus, 1980; Fischer et al., 1981) and in vivo the loss of alanine ester from LTA is compensated for by re-alanylation (Haas et al., 1984; Koch et al., 1985). 


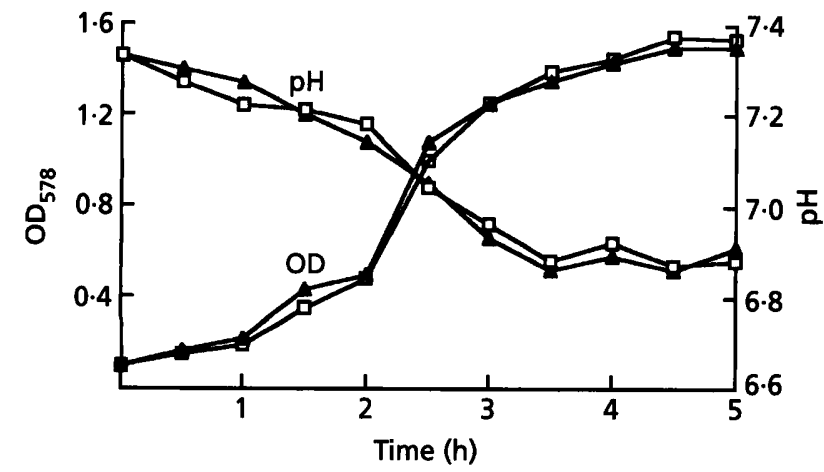

Fig. 1. Growth curve and concomitant decrease of $\mathrm{pH}$ for the wild-type strain JH642 ( $\square$ ) and the mutant DLT74A ( $\mathbf{A}$ ).

Table 1. Binding of cytochrome $c$ by $B$. subtilis

Strains JH642 and DLT76 contain D-alanine ester in LTA and WTA; strains DLT74A, DLT77, DLT72, DLT65A contain no alanine ester in these polymers. Binding of cytochrome $c$ was expressed as $\Delta A_{526}$, the difference between the absorbance of the solution containing the initial concentration of cytochrome $c$ and that of the supernatant following incubation with the bacteria. Initial concentrations of cytochrome $c$ : (a) $500 \mu \mathrm{g} \mathrm{ml}^{-1}$ $(38.5 \mu \mathrm{M}), A_{526 \mathrm{i}} 0.327$; (b) $750 \mu \mathrm{g} \mathrm{ml}^{-1}(57.7 \mu \mathrm{M}), A_{5261} 0.458$.

\begin{tabular}{|lcc|}
\hline Strain tested & \multicolumn{2}{c|}{$\Delta A_{526}$} \\
\cline { 2 - 3 } & $(\mathrm{a})$ & (b) \\
\hline JH642 & 0.088 & $0 \cdot 111$ \\
DLT76 & 0.061 & $0 \cdot 086$ \\
DLT74A & 0.137 & $0 \cdot 181$ \\
DLT77 & 0.139 & $0 \cdot 161$ \\
DLT72 & 0.147 & 0.171 \\
DLT65A & 0.191 & 0.213 \\
\hline
\end{tabular}

\section{Cellular content of LTA, WTA and other phosphorus- containing compounds}

Irrespective of whether LTA and WTA was alanylated or alanine-free, the cells contained on average, ( $\mathrm{g}$ dry mass) $)^{-1}$ : $1139 \pm 85 \mu \mathrm{mol}$ total phosphorus, $818 \pm$ $42 \mu \mathrm{mol}$ nucleic acid phosphorus, $346 \pm 25 \mu \mathrm{mol}$ WTA phosphorus, and $62 \pm 4 \mu \mathrm{mol}$ LTA phosphorus. Moreover, examination by electron microscopy indicated that the cell walls had the same thickness. Accordingly, the results presented below refer to the same amount of WTA and LTA, and therefore reflect the difference between purely anionic and partially alanylated polymers.

\section{Detection of negative charges on bacterial surfaces by cytochrome $c$}

Binding of the positively charged cytochrome $c$ with its contrast-delivering iron atom served to identify the negative charges on the bacterial surfaces. Table 1

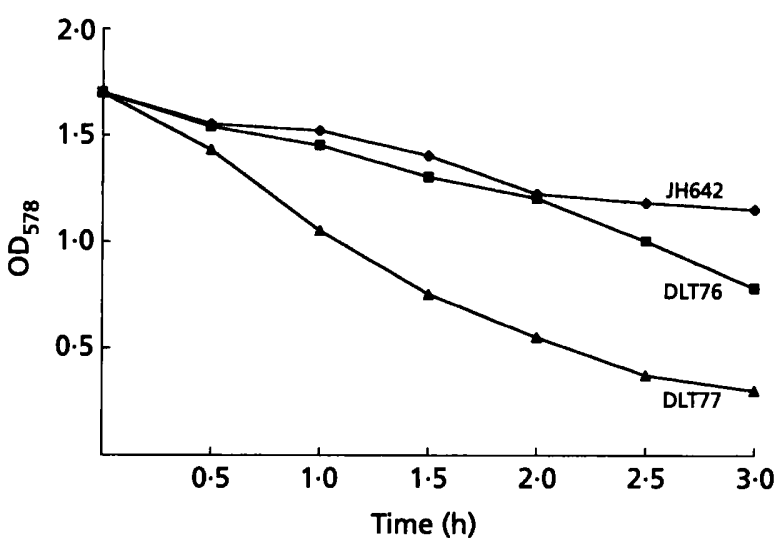

Fig. 2. Autolysis of bacteria in $0.1 \mathrm{M}$ HEPES buffer, $\mathrm{pH} 7 \cdot 1$. Bacteria in the exponential phase of growth $\left(O D_{578} 0.8\right)$ were harvested by centrifugation $\left(7000 \mathrm{~g}, 4^{\circ} \mathrm{C}, 10 \mathrm{~min}\right.$ ) washed twice with cold $0.1 \mathrm{M}$ HEPES buffer, $\mathrm{pH} 7 \cdot 1$, suspended in this buffer to $O D_{578} 1 \cdot 6$, and incubated at $32{ }^{\circ} \mathrm{C}$ with shaking (150 r.p.m.).

shows that the mutant strains of B. subtilis with no Dalanylation of LTA and WTA bound approximately twice as much cytochrome $c$ as the wild-type JH642 and the mutant strain DLT76, which both contain Dalanylated LTA and WTA. These data demonstrate that the absence of D-alanylation of LTA and WTA led to increased availability of anionic binding sites.

\section{Cell autolysis}

The mutant strains of $B$. subtilis with alanine-free LTA offered the opportunity to analyse the influence of the Dalanyl groups on the activity of wall autolysins using isogenic cells. Exponentially growing bacteria were harvested and incubated in $0.1 \mathrm{M}$ HEPES buffer at $\mathrm{pH} 7 \cdot 1$ at $32^{\circ} \mathrm{C}$. Autolysis was followed by measuring $\mathrm{OD}_{578}$. As shown in Fig. 2, the mutant strain DLT77 autolysed at a higher rate than either strain with Dalanylated LTA and WTA (JH642, DLT76).

\section{Sensitivity of different B. subtilis strains to methicillin}

A sensitive indicator of metabolic disturbances is the metabolic heat production measured by flow microcalorimetry (Krüger \& Giesbrecht, 1989). As shown in Fig. 3, there was no difference in the heat production profile of the wild-type strain JH642 and the mutant strain DLT74A. Under the influence of methicillin, the typical heat production profile was altered. While the heat output curve of the mutant strain declined to zero, the wild-type strain maintained a higher level of heat output.

The higher methicillin sensitivity of the mutant strain DLT74A was also reflected by the viable counts of the culture. Viability of the mutant strain declined faster than that of the wild-type strain JH642, resulting in a difference of two orders of magnitude after $2 \mathrm{~h}$ (Fig. 3). 

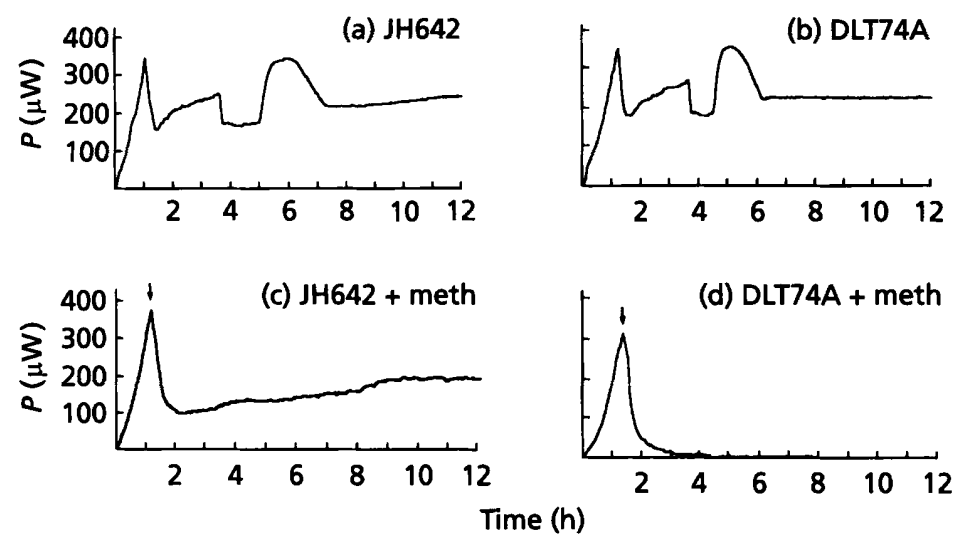

Fig. 3. (a-d) Heat production $(P, \mu W)$ in cultures of the wild-type JH642 and the mutant DLT74A in the absence and presence of methicillin $\left(0.35 \mu \mathrm{g} \mathrm{ml} \mathrm{m}^{-1}\right)$. Methicillin (meth) was added to exponentially growing

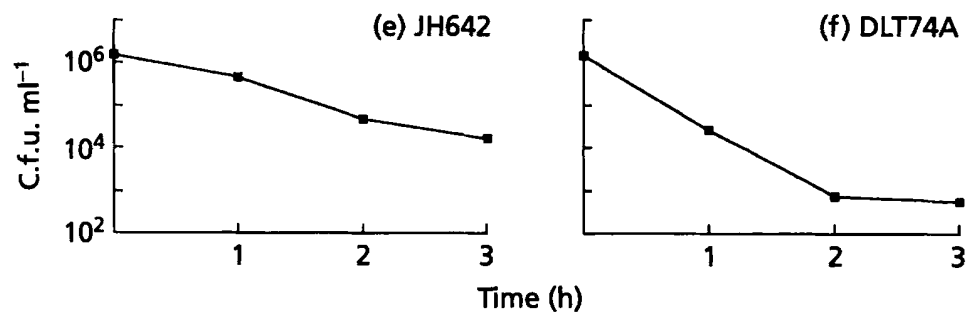
bacteria $\left(O D_{578} 0.5\right)$ at a heat output as indicated by the arrow. $(e, f)$ Influence of methicillin $\left(0.3 \mu \mathrm{g} \mathrm{ml}^{-1}\right)$ on the viability (c.f.u. $\mathrm{ml}^{-1}$ ) of exponentially growing cells. Methicillin was added at time zero. Samples were taken at the times indicated, diluted with growth medium, and aliquots $(92.2 \mu \mathrm{l})$ were spread on agar plates using a spiral plater (Spiral Systems). Colonies were counted after incubation at $37^{\circ} \mathrm{C}$ for $20 \mathrm{~h}$.

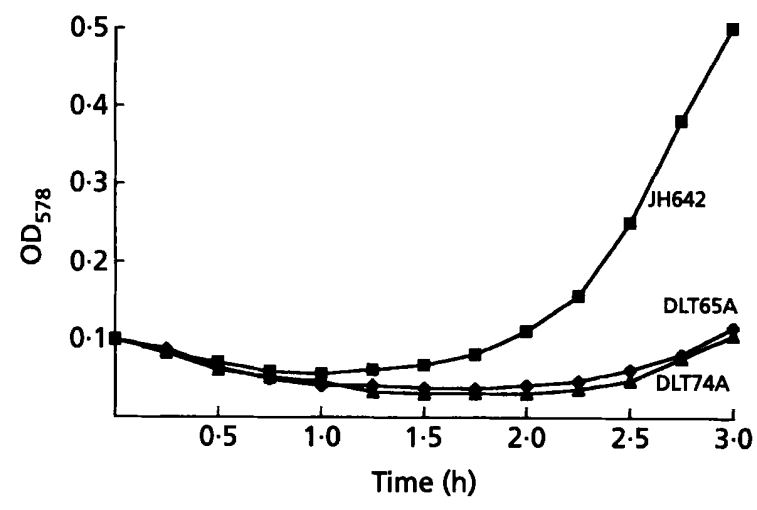

Fig. 4. The postantibiotic effect was followed spectrometrically as described by Rescott et al. (1988). Bacteria in the exponential phase of growth $\left(O D_{578} 0.4\right)$ were exposed to methicillin $\left(0.35 \mu \mathrm{g} \mathrm{ml} \mathrm{m}^{-1}\right)$ at $37^{\circ} \mathrm{C}, 1 \mathrm{~h}$. The antibiotic was removed by centrifugation $(4000 \mathrm{~g}, 5 \mathrm{~min})$ and washing the bacteria three times with growth medium. The bacteria were then resuspended in pre-warmed growth medium and reincubated at $37^{\circ} \mathrm{C}$ on a rotary shaker (150 r.p.m.). $O D_{578}$ was measured at the times indicated.

\section{The postantibiotic effect after treatment with methicillin}

After short treatment of the bacteria with methicillin $(1 \mathrm{~h})$, the subsequent regrowth in antibiotic-free medium showed remarkable differences between the wild-type and the mutant strains (Fig. 4). The wild-type JH642 exhibited a decrease in optical density during the first hour. Then rapid growth followed. In the case of the two mutants with alanine-free LTA (DLT65A,
DLT74A) the period of decreasing optical density continued for more than $2 \mathrm{~h}$ and the rate of subsequent regrowth was, at least over the time period studied, approximately one-fifth of the recovery rate observed with the parent strain. Thus the postantibiotic effect also demonstrated that $\mathrm{D}$-alanylation reduced sensitivity to methicillin.

\section{Relief from methicillin effects by $\mathbf{M g}^{2+}$ ions}

Since $\mathrm{Mg}^{2+}$ ions were shown earlier to interfere with penicillin-induced lysis of $S$. aureus (Kersten $\&$ Wecke, 1993), we tested the effect of $\mathrm{MgCl}_{2}$ on methicillininduced lysis, heat production and viability of the parent strain JH642 and the mutant DLT74A. The results are summarized in Fig. 5. Compared with the addition of methicillin alone, the concomitant addition of $\mathrm{MgCl}_{2}$ prevented autolysis in both the wild-type and the mutant strain. The lysis-protective effect of $\mathrm{MgCl}_{2}$ was also reflected in the heat output curves $(P, \mu \mathrm{W})$, which, compared with the curves in Fig. 3, suggest an approach to normal metabolism in both the parent and the mutant strain. Compared with Fig. 3, the effect of methicillin on the viability (c.f.u. $\mathrm{ml}^{-1}$ ) was also strongly reduced by $\mathrm{MgCl}_{2}$. The viability moderately increased in the wildtype strain and only slowly decreased in the mutant.

The protective effect of $\mathrm{MgCl}_{2}$ could also be visualized by electron microscopy. Fig. 6(a) shows cells during normal growth and Fig. 6(b) the high degree of cell lysis caused by methicillin $\left(0 \cdot 3 \mu \mathrm{g} \mathrm{ml}^{-1}\right)$. Fig. 6(c) shows the effect of simultaneous addition of methicillin $(0.3 \mu \mathrm{g}$ $\left.\mathrm{ml}^{-1}\right)$ and $\mathrm{MgCl}_{2}(0 \cdot 5 \mathrm{mM}):$ the cells no longer lyse, they show irregular cell shape, irregular apposition of cell 

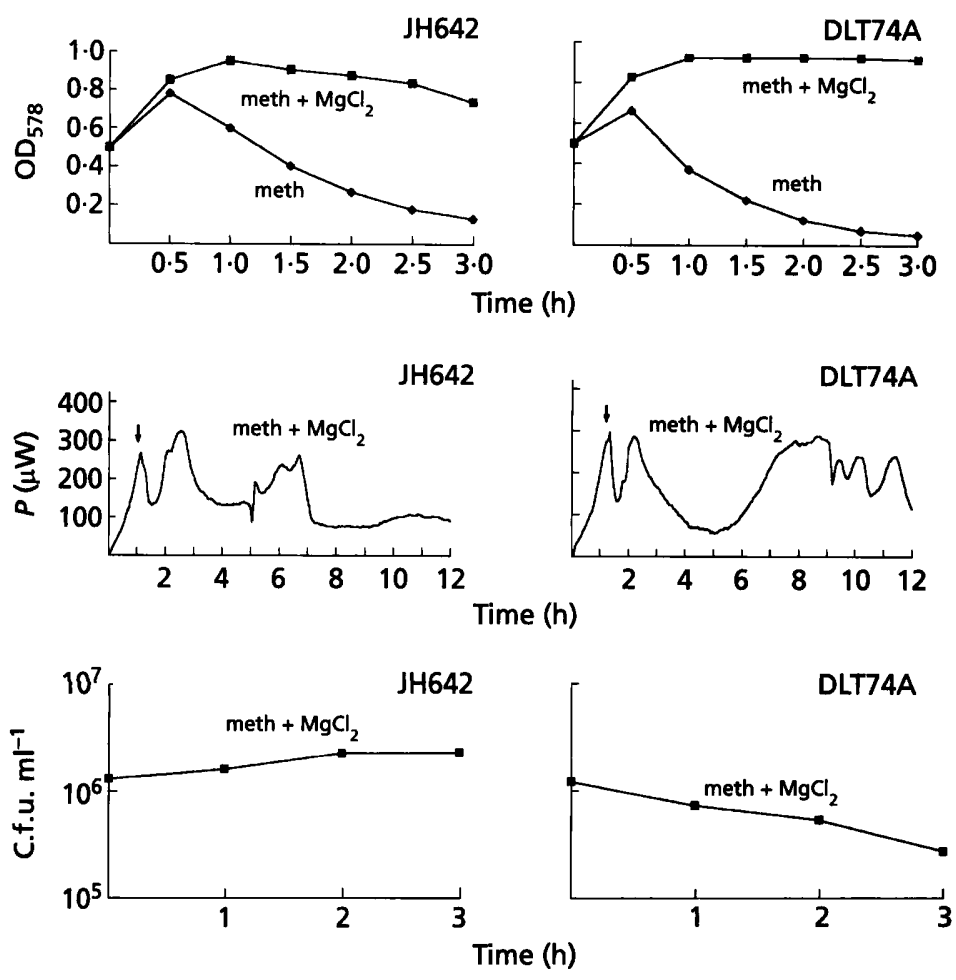

Fig. 5. Effect of $\mathrm{MgCl}_{2}(5 \cdot 25 \mathrm{mM})$ on methicillin-induced lysis, heat production $(P$, $\mu \mathrm{W}$ ) and viability (c.f.u. $\mathrm{ml}^{-1}$ ). $\mathrm{MgCl}_{2}$ was added simultaneously with methicillin (meth, $0.35 \mu \mathrm{g} \mathrm{ml}^{-1}$ ). Experimental details were the same as for Fig. 3. For the effect of methicillin in the absence of $\mathrm{MgCl}_{2}$ see Fig. 3. wall material, variability of cell size, and the formation of mini-cells. At a tenfold higher magnification (Fig. 7) these alterations are seen in more detail. Mini-cells were identified by analysing the cell wall. If a definite wall could be detected, the thin section was cut from a rather central part of the cell. Caps or peripheral parts of the cell could be identified by the unclear border between cell wall and cytoplasma and the outside, respectively.

\section{Phagocytosis of radiolabelled bacteria and cell wall degradation by macrophages}

Ester-linked D-alanine residues are common substituents of both LTA and WTA in many Gram-positive bacteria. Among them are potential pathogens, such as enterococci, group A streptococci, Listeria monocytogenes and staphylococci. It is therefore an important question whether alanylation of LTA and WTA protects pathogens from phagocytosis and degradation by macrophages. The wild-type and the isogenic mutants of $B$. subtilis provided for the first time the opportunity to address this question. The cell walls of the wild-type JH642 and the isogenic mutant strains DLT65A and DLT74A were specifically labelled by growing the bacteria in the presence of $\mathrm{N}$-acetyl-D- $\left[1-{ }^{14} \mathrm{C}\right]$ glucosamine. The labelled bacteria were incubated with bonemarrow-derived macrophages and the ${ }^{14} \mathrm{C}$ radioactivity released into the supernatant served as a measure of phagocytosis and cell-wall lysis. The results, summarized in Table 2, show that over a time period of $72 \mathrm{~h}$ in which more than $60 \%$ of the radiolabel was released, there was no difference between the wild-type, containing D-alanine ester in LTA and WTA, and the two mutant strains with no D-alanine ester in LTA or WTA. We may therefore conclude that the surface charge of the ingested bacteria plays no role in the degradation of cell walls within phagocytes.

\section{DISCUSSION}

There is considerable evidence that the charge of the cell wall is important for the activity of the cationic autolytic enzymes. Studies on isolated walls of B. subtilis indicated that negative charges are due to phosphate groups of teichoic acids and carboxyl groups of murein (Sonnenfeld et al., 1985). Until now, however, it has not been known to what extent the positively charged D-alanine ester substituents of lipoteichoic acid and wall teichoic acid contribute to the net charge of the cell walls. Our recent measurements revealed for $B$. subtilis $\mathrm{JH} 642$ approximately $350 \mu \mathrm{mol}$ WTA phosphorus and $60 \mu \mathrm{mol}$ LTA phosphorus (g dry cells) ${ }^{-1}$ and D-alanine/phosphorus molar ratios of 0.09 and 0.5 , respectively (Perego et al., 1995). Accordingly, lack of $\mathrm{D}$-alanine ester, as shown here for the mutant strains, is expected to increase the net negative charge of WTA by $9 \%$ and that of LTA by $50 \%$. In a recent electron microscopic study we tried to detect these charge differences by using cationized ferritin (molar mass $>5 \times 10^{5} \mathrm{kDa}$ ) but found no difference between the parent and the mutant strains (Wecke et al., 1996). In both cases iron-containing ferritin granules were visible on the outer surface of the cell. In the present study, we used cytochrome $c$, which is much smaller $(13 \mathrm{kDa})$, and using a spectrophotometric procedure we found the amount of cytochrome $c$ bound by the mutant strains was more than double that 


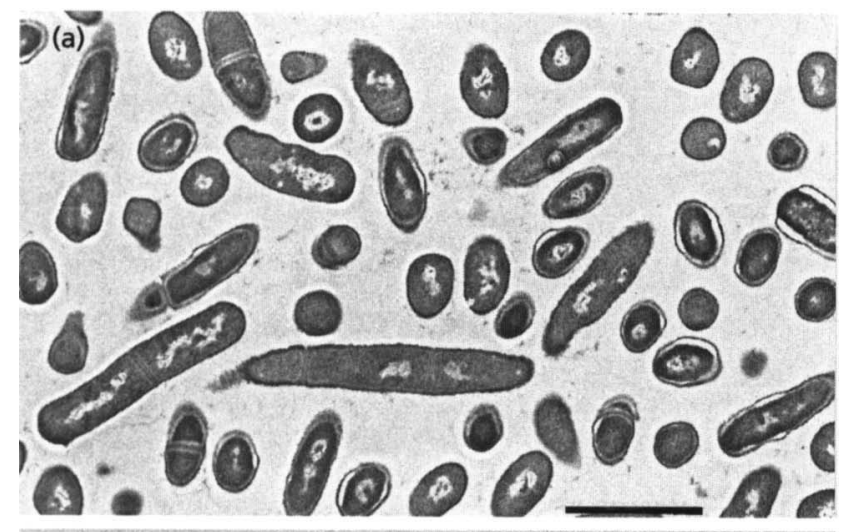

(b)
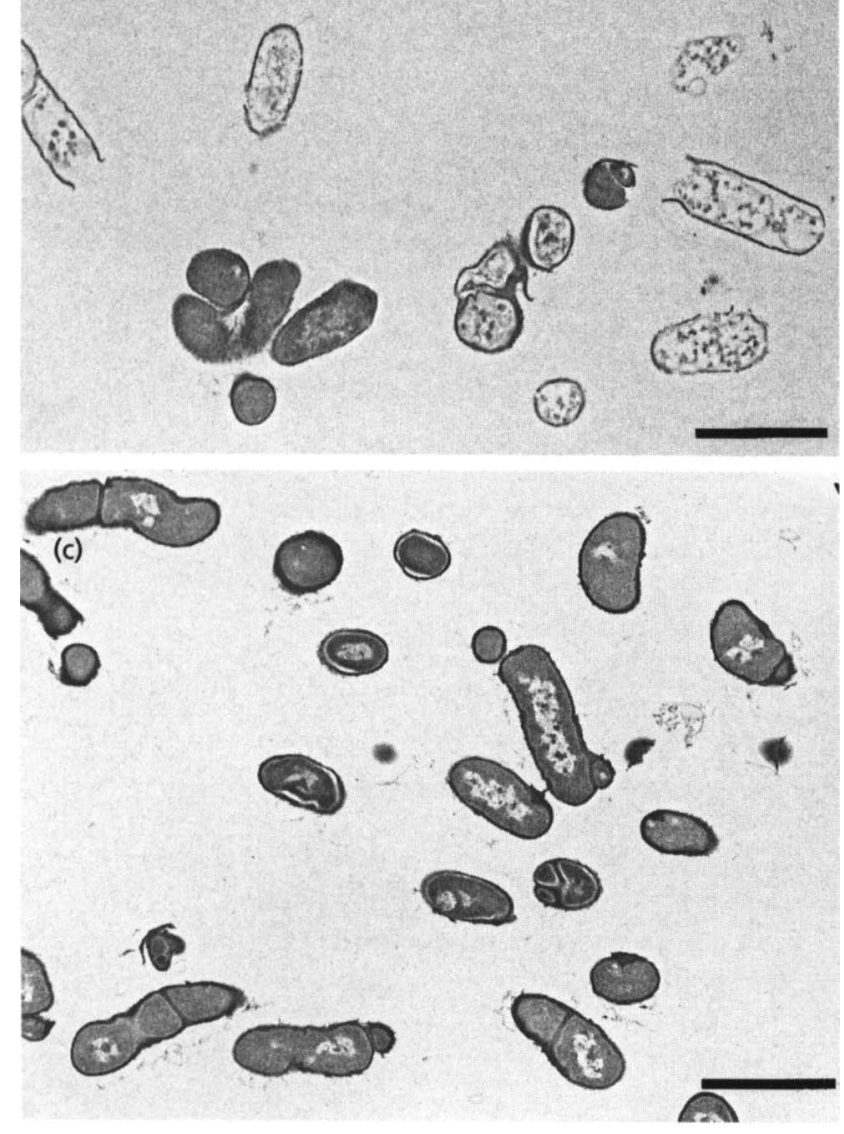

Fig. 6. Ultrathin sections of cells of B. subtilis DLT77. Samples were taken (a) after normal growth; (b) $3 \mathrm{~h}$ after addition of methicillin $\left(0.3 \mu \mathrm{g} \mathrm{ml}^{-1}\right)$; (c) $3 \mathrm{~h}$ after simultaneous addition of methicillin $\left(0.3 \mu \mathrm{g} \mathrm{ml}^{-1}\right)$ and $\mathrm{MgCl}_{2}(0.5 \mathrm{mM})$. Bars, $2 \mu \mathrm{m}$.

of the wild-type at subsaturating cytochrome concentrations. Additionally, thin sections revealed heterogeneous distribution of the negative charges, in so far as the cylindrical part of the cell wall showed more cytochrome $c$ label than the cross walls which had just separated (not shown). A similar difference has been previously reported and ascribed to differences in the level of teichoic acid (Graham \& Beveridge, 1994; Mauël et al., 1995).
The inhibitory action of negatively charged LTA on cationic autolysins is well established (Cleveland et al., 1975, 1976; Suginaka et al., 1979; Fischer et al., 1981, Fischer, 1988). It is inversely related to the D-alanine ester content (Fischer et al., 1981; Bierbaum \& Sahl, 1991) and one would therefore expect autolytic activity to be lower in the mutant strains lacking $\mathrm{D}$-alanine ester substitution. However, just the reverse is true: they show an increase of autolysis and methicillin-induced lysis. As pointed out previously (Wecke et al., 1996), however, the earlier experiments were carried out with LTAs present as micelles, which have a high negative surface charge (Labischinski et al., 1991). Accordingly, micelles may trap cationic autolysin on their surface and prevent its access to the cell-wall substrate. The situation in the living cell may be different because in the cytoplasmic membrane LTA molecules are separated by membrane lipids (Gutberlet et al., 1991) and an increased negative charge may therefore increase the capacity to bind and retain the cationic autolysins. Support for this hypothesis comes from in vitro experiments in which deacylation of LTA or dilution of the charges by embedding LTA into Triton X-100 micelles abolished the inhibitory effect (Cleveland et al., 1976; Fischer et al., 1981). Further support is derived from studies on vancomycin-resistant Enterococcus faecium D366 mutants in which inducible and constitutively expressed resistance was associated with drastically decreased endogenous and $\beta$-lactam-induced lysis (Gutmann et al., 1996). This phenomenon could be neither related to changes in the cell wall nor to alteration of autolysin. The only changed parameter was a doubling of the D-alanine ester content of LTA, which might have decreased the binding capacity for autolysins.

Consistent with this proposition are the observations that the $N$-acetylmuramyl-D-alanine amidase, a major autolytic enzyme of $B$. subtilis, is tightly bound to homologous teichoic acid, possibly by electrostatic interaction (Herbold \& Glaser, 1975) and that mutants deficient in teichoic acid are usually also deficient in cellwall-lytic enzymes (Chatterjee et al., 1969; Boylan et al., 1972; Fiedler \& Glaser, 1973). Moreover, the induction of autolysis of Staphylococcus simulans by cationic group A lantibiotics was proposed to be caused by a competitive release of the cationic autolysins from negatively charged LTA and WTA (Bierbaum \& Sahl, 1991).

The mechanism which triggers endogenous and $\beta$ lactam-induced lysis is not yet known. But when the autolytic enzymes are put into operation, the amount of enzyme available seems to decide the magnitude of the effect. Among the diverse effects evoked by methicillin, the primary event seems to be cell lysis (Fig. 6b), which reduces the number of living cells and leads to a breakdown of metabolic heat production (Fig. 3). It is further reflected in the postantibiotic period, during which the recovery of the less damaged alanine-containing cells is much faster than that of the mutant strain (Fig. 4). Confirmative support for this sequence of events comes from the observation that they can be diminished 


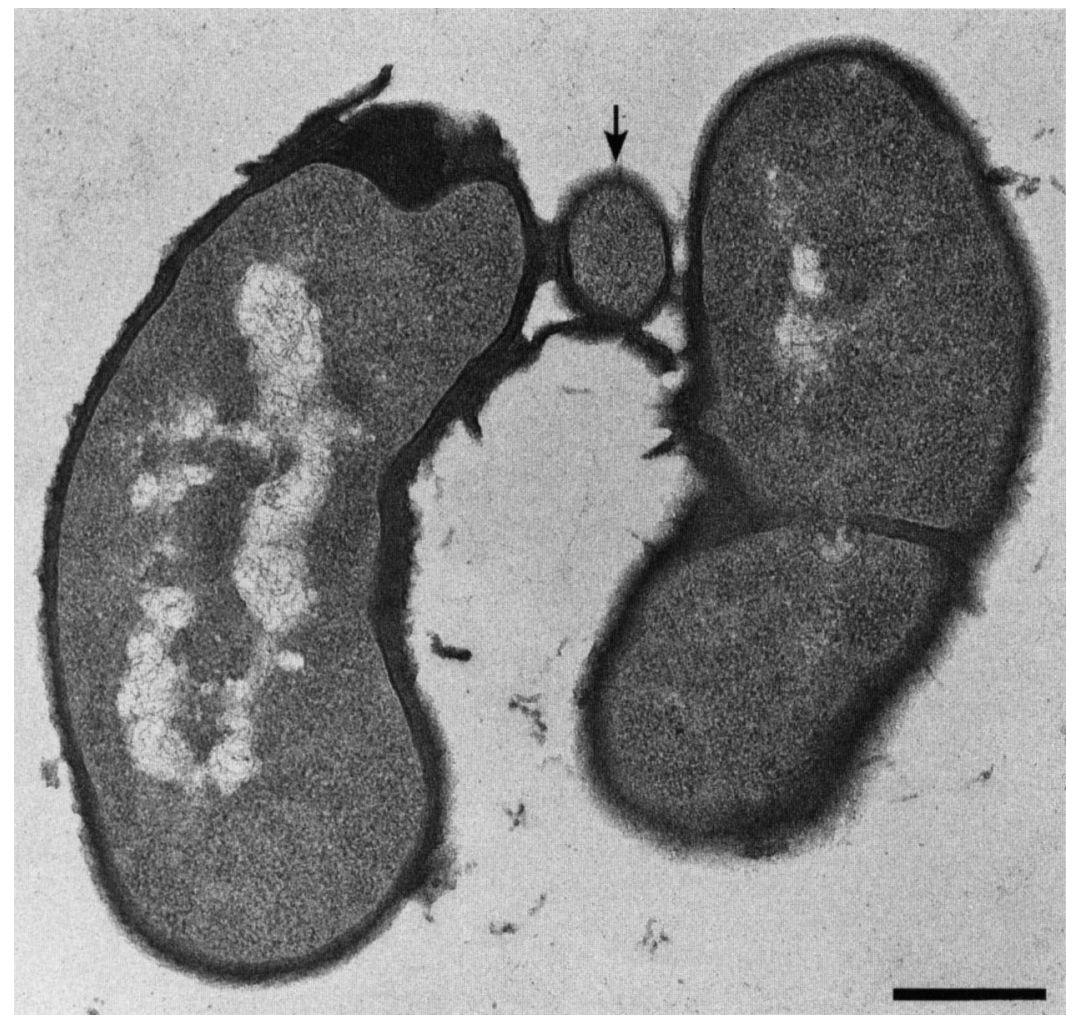

Fig. 7. Ultrathin section of cells of $B$. subtilis DLT77 after synchronous treatment with methicillin $\left(0.3 \mu \mathrm{g} \mathrm{ml}^{-1}\right)$ and $\mathrm{MgCl}_{2}(0.5 \mathrm{mM})$ for $3 \mathrm{~h}$. The arrow indicates a mini-cell. Bar, $0.2 \mu \mathrm{m}$.

Table 2. Release of ${ }^{14} \mathrm{C}$ from macrophages after ingestion of wild-type and mutants whose cell walls had been labelled with $\mathrm{N}$-acetyl-D-[1-14 C]glucosamine

\begin{tabular}{|lllll|}
\hline Strain tested & \multicolumn{4}{c|}{ Percentage of ${ }^{14} \mathrm{C}$ label released after: } \\
\cline { 2 - 5 } & $\mathbf{3 ~ h}$ & $\mathbf{2 4} \mathbf{h}$ & $\mathbf{4 8 ~ h}$ & $\mathbf{7 2 ~ h}$ \\
\hline JH642 & $29 \cdot 8$ & $48 \cdot 4$ & $60 \cdot 3$ & $69 \cdot 5$ \\
DLT65A & $30 \cdot 9$ & $46 \cdot 1$ & $59 \cdot 6$ & $68 \cdot 9$ \\
DLT74A & $27 \cdot 1$ & $44 \cdot 3$ & $54 \cdot 9$ & $67 \cdot 2$ \\
\hline
\end{tabular}

or stopped synchronously by the addition of $\mathrm{Mg}^{2+}$ ions (Figs 5, 6c). The mode of action of $\mathrm{Mg}^{2+}$ ions in our experiments is not yet understood. It has been well established that the $\mathrm{N}$-acetylmuramyl-L-alanine amidase of $B$. subtilis requires divalent metal ions for activity. $\mathrm{Mg}^{2+}$ ions at concentrations from 0.5 to $50 \mathrm{mM}$ with a maximum at $20 \mathrm{mM}$ have an activating effect (Foster, 1991; Herbold \& Glaser, 1975; Rogers et al., 1984), whereas the results of our experiments suggest a depressing effect on methicillin-induced lysis at $\mathbf{M g}^{2+}$ concentrations as low as $0.5 \mathrm{mM}$ and $2.5 \mathrm{mM}$ (Figs 5 , 6c).

The widespread occurrence of alanylated LTA and WTA among Gram-positive bacteria prompted us to study the effect of alanine substitution on the degradation of bacterial cells in macrophages. There was, however, no difference between the wild-type, whose
LTA and WTA contain D-alanine ester, and the mutant strains, in which these polymers lack D-alanine ester. This observation strongly suggests that alanylation is not a means to protect Gram-positive pathogens from degradation by macrophages in the mammalian host.

\section{REFERENCES}

Bierbaum, G. \& Sahl, H. G. (1991). Induction of autolysis of Staphylococcus simulans 22 by Pep5 and nisin and influence of the cationic peptides on the activity of the autolytic enzymes. In Nisin and Novel Antibiotics, pp. 386-396. Edited by G. Jung \& H. G. Sahl. Leyden: ESCOM.

Boylan, R. J., Mendelson, N. H., Brooks, D. \& Young, F. E. (1972). Regulation of the bacterial cell wall: analysis of a mutant of Bacillus subtilis defective in biosynthesis of teichoic acid. $J$ Bacteriol 110, 281-290.

Chatterjee, A. N., Mirelman, D., Singer, H. J. \& Park, J. T. (1969). Properties of a novel pleiotropic bacteriophage-resistant mutant of Staphylococcus aureus H. J Bacteriol 100, 846-853.

Childs, W. C., III \& Neuhaus, F. C. (1980). Biosynthesis of D-alanyllipoteichoic acid: characterization of ester-linked $\mathrm{D}$-alanine in the in vitro-synthesized product. J Bacteriol 143, 293-301.

Cleveland, R. F., Holtje, J. V., Wicken, A. J., Tomasz, A., DaneoMoore, L. \& Shockman, G. D. (1975). Inhibition of bacterial wall lysins by lipoteichoic acids and related compounds. Biochem Biophys Res Commun 67, 1128-1135.

Cleveland, R. F., Daneo-Moore, L., Wicken, A. J. \& Shockman, G. D. (1976). Effect of lipoteichoic acid and lipids on lysis of intact cells of Streptococcus faecalis. J Bacteriol 127, 1582-1584.

Debabov, D. V., Heaton, M. P, Zhang, Q., Stewart, K. D., Lambalot, R. H. \& Neuhaus, F. C. (1996). The D-alanyl carrier 
protein in Lactobacillus casei : cloning, sequencing and expression of dltC. J Bacteriol 178, 3869-3876.

Fiedler, F. \& Glaser, L. (1973). Assembly of bacterial cell walls. Biochim Biophys Acta 300, 467-485.

Fischer, W. (1988). Physiology of lipoteichoic acids in bacteria. Adv Microb Physiol 29, 233-302.

Fischer, W., Rosel, P. \& Koch, H. U. (1981). Effect of alanine ester substitution and other structural features of lipoteichoic acids on their inhibitory activity against autolysins of Staphylococcus aureus. J Bacteriol 146, 467-475.

Foster, S.-J. (1991). Cloning, expression, sequence analysis and biochemical characterization of an autolytic amidase of Bacillus subtilis 168 trpC2. J Gen Microbiol 137, 1987-1998.

Graham, L. L. \& Beveridge, T. J. (1994). Structural differentiation of the Bacillus subtilis 168 cell wall. J Bacteriol 176, 1413-1421.

Gutberlet, T., Markwitz, S., Labischinski, H. \& Bradaczek, H. (1991). Monolayer investigations on the bacterial amphiphile lipoteichoic acid and on lipoteichoic acid/dipalmitoylphosphatidylglycerol mixtures. Makromol Chem Macromol Symp 46, 283-287.

Gutmann, L., Al-Obeid, S., Billot-Klein, D., Ebnet, E. \& Fischer, W. (1996). Penicillin tolerance and modification of lipoteichoic acid associated with expression of vancomycin resistance in Van BType Enterococcus faecium D366. Antimicrob Agents Chemother 40, 257-259.

Haas, R., Koch, H. U. \& Fischer, W. (1984). Alanyl turnover from lipoteichoic acid to teichoic acid in Staphylococcus aureus. FEMS Microbiol Lett 21, 27-31.

Heaton, M. P. \& Neuhaus, F. C. (1992). Biosynthesis of D-alanyl lipoteichoic acid: cloning, nucleotide sequence, and gene expression of the Lactobacillus casei gene for D-alanine activating enzyme. J Bacteriol 174, 4707-4717.

Heaton, M. P. \& Neuhaus, F. C. (1994). Role of D-alanyl carrier protein in the biosynthesis of D-alanyl-lipoteichoic acid. $J$ Bacteriol 176, 681-690.

Herbold, D. R. \& Glaser, L. (1975). Bacillus subtilis $N$-acetylmuramic acid L-alanine amidase. J Biol Chem 250, 1676-1682.

Holtje, J.-V. \& Tomasz, A. (1975). Lipoteichoic acid: a specific inhibitor of autolysin activity in Pneumococcus. Proc Natl Acad Sci USA 72, 1690-1694.

Hughes, A. H., Hancock, I. C. \& Baddiley, J. (1973). The function of teichoic acids in cation control in bacterial membranes. Biochem J 132, 83-93.

Kersten, T. \& Wecke, J. (1993). Delayed penicillin-induced bacteriolysis of staphylococci by some cations. In : Fifty Years of Penicillin Application, History and Trends, pp. 364-372. Edited by H. Kleinkauf \& H. von Döhren. Prague: Public.
Koch, H. U., Dobker, R. \& Fischer, W. (1985). Maintenance of Dalanine ester substitution of lipoteichoic acid by re-esterification in Staphylococcus aureus. J Bacteriol 164, 1211-1217.

Kruger, D. \& Giesbrecht, P. (1989). Flow microcalorimetry as a tool for an improved analysis of antibiotic activity: the different stages of chloramphenicol action. Experientia 45, 322-325.

Labischinski, H., Naumann, D. \& Fischer, W. (1991). Small and medium angle $\mathrm{X}$-ray analysis of bacterial lipoteichoic acid phase structure. Eur J Biochem 202, 1269-1274.

Lambert, P. A., Hancock, I. C. \& Baddiley, J. (1975). Influence of alanyl ester residues on the binding of magnesium ions to teichoic acids. Biochem J 151, 671-676.

Lambert, P. A., Hancock, I. C. \& Baddiley, J. (1977). Occurrence and function of membrane teichoic acids. Biochim Biophys Acta 472, 1-12.

Mauël, C., Bauduret, A., Chervet, C., Beggah, S. \& Karamata, D. (1995). In Bacillus subtilis 168, teichoic acid of the cross-wall may be different from that of the cylinder: a hypothesis based on transcription analysis of tag genes. Microbiology 141, 2379-2389.

Neuhaus, F. C., Heaton, M. P., Debabov, D. V. \& Zhang, Q. (1996). The dlt operon in the biosynthesis of $\mathrm{D}$-alanyl lipoteichoic acid in Lactobacillus casei. Microb Drug Resist 2, 77-84.

Perego, M., Glaser, P., Minutello, A., Strauch, M. A., Leopold, K. \& Fischer, W. (1995). Incorporation of $\mathrm{D}$-alanine into lipoteichoic acid and wall teichoic acid in Bacillus subtilis. J Biol Chem 270, 15598-15606.

Rescott, D. L., Nix, D. E., Holden, P. \& Schentag, J. J. (1988). Comparison of two methods for determining in vitro postantibiotic effects of three antibiotics on Escherichia coli. Antimicrob Agents Chemother 32, 450-453.

Rogers, H. J., Taylor, C., Rayter, S. \& Ward, J. B. (1984). Purification and properties of autolytic endo- $\beta$ - $N$-acetylglucosaminidase and the $N$-acetylmuramyl-L-alanine amidase from Bacillus subtilis strain 168. J Gen Microbiol 130, 2395-2402.

Sonnenfeld, E. M., Beveridge, T. J., Koch, A. L. \& Doyle, R. J. (1985). Asymmetric distribution of charge on the cell wall of Bacillus subtilis. J Bacteriol 163, 1167-1171.

Suginaka, H., Shimatani, M., Ohno, Y. \& Yano, I. (1979). Effects of bacterial lipids and lipoteichoic acid on extracellular autolysin activity from Staphylococcus aureus. FEMS Microbiol Lett 5, 353-355.

Wecke, J., Perego, M. \& Fischer, W. (1996). D-Alanine deprivation of Bacillus subtilis teichoic acids is without effect on cell growth and morphology but affects the autolytic activity. Microb Drug Resist 2, 123-129.

Received 29 November 1996; revised 19 May 1997; accepted 2 June 1997. 